$\$$ Research Square

\title{
Agricultural subsidies and global greenhouse gas emissions
}

Rob Vos ( $\nabla$ r.vos@cgiar.org)

International Food Policy Research Institute https://orcid.org/0000-0003-0288-050X

David Laborde Debucquet

IFPRI-Washington, DC

William Martin

International Food Policy Research Institute

Valeria Pineiro

International Food Policy Research Institute

Abdullah Mamun

International Food Policy Research Institute

\section{Article}

Keywords: Agricultural Production, Land Use Change, Agricultural Support Programs, Climate Change Mitigation

Posted Date: November 16th, 2020

DOI: https://doi.org/10.21203/rs.3.rs-84153/v1

License: (c) (i) This work is licensed under a Creative Commons Attribution 4.0 International License. Read Full License

Version of Record: A version of this preprint was published at Nature Communications on May 10th, 2021. See the published version at https://doi.org/10.1038/s41467-021-22703-1. 


\title{
Agricultural subsidies and global greenhouse gas emissions
}

David Laborde ${ }^{1}$, Abdullah Mamun ${ }^{1}$, Will Martin ${ }^{1}$, Valeria Piñeiro ${ }^{1}$ \& Rob Vos*1

${ }^{1}$ International Food Policy Research Institute

* Corresponding author: Rob Vos, International Food Policy Research Institute, 1201 I Street

N.W., Washington D.C. 20007, USA, email: r.vos@cgiar.org; T. +1-3475220162

\section{Sections}

\author{
Abstract \\ Main text \\ Tables and figures \\ References \\ Methods section (including tables, figures and references to Methods) \\ Supplementary Table
}

\section{Acknowledgements}

This article was written as part of work undertaken for the Food and Land Use Coalition and a World Bank project on the "Environmental Impacts of Agricultural Support: Aligning Food Security and Climate Protection Objectives." Funding for this research was provided by The World Bank and the CGIAR Research Program on Policies, Institutions and Markets (PIM). The authors are grateful to Madhur Gautam, Raffaello Cervigni, Richard Damania, Mike Toman, Stephen Ling, Dina UmaliDeininger, and Sergiy Zorya of the World Bank and to participants at an IFPRI policy seminar (21 April 2020); an NBER conference (30 April 2020); and the GTAP Conference (17 June 2020) for helpful comments on earlier versions of this study.

\section{Author contributions}

All authors. D.L., A.M., W.M., V.P., and R.V., have contributed substantially and equally to the manuscript in terms of concept development, scenario design, analysis of model simulation results and final write-up.

\section{Competing interests}

The authors declare no competing interests.

\section{Additional information}

Extended data and supplementary information is available for this paper at https://tinyurl.com/yyj9zwn2 and https://tinyurl.com/y4cvmv5v.

Correspondence and requests for materials should be addressed to R.V. 


\title{
Agricultural subsidies and global greenhouse gas emissions
}

\begin{abstract}
Agricultural production is both strongly affected by climate change and a major contributor to climate change, with agriculture and land use change accounting for around a quarter of total global emissions of greenhouse gases. Agricultural production benefits from substantial government support, costing around US\$600 billion per year worldwide. These subsidies clearly affect greenhouse gas emissions by influencing the composition and location of output, and production practices, but no rigorous quantification of these impacts have been available to date. This article fills this void. Overall, we find small impacts of agricultural support programs on output and hence on emissions. Abolishing support altogether thus would do little to reduce global emissions from agriculture. In fact, paradoxically, it could even increase emissions. A repurposing of support towards incentives for more resource-efficient and climate-smart forms of production needs to be considered if this support is to contribute to climate change mitigation, adaptation and food security.
\end{abstract}

During 2017-2019, farm sectors in 54 major economies received together US\$553 billion per year in the form of market price support and direct subsidies. Of this amount, US\$446 billion (equivalent to $12.5 \%$ of gross farm receipts) was provided as direct subsidies and "market price support" through trade measures (Fig. 1 and ref. ${ }^{1}$ ). These direct subsidies are either "coupled" to output levels and input use, or "decoupled" from specific production and provided as direct payments to farmers. The 54 countries for which such data are collected by the OECD also spent US\$106 billion per year on "General Services Support" policies designed to create enabling conditions for agriculture, such as agricultural innovation systems, sanitary and phytosanitary standards and rural infrastructure.

The two components of support that influence output decisions most directly are subsidies coupled to output and market price support provided through trade measures. Coupled subsidies tend to increase output without lowering demand in the subsidizing countries and hence to increase global emissions. Market price support tends to increase supply in protecting regions but, at the same time, reduces demand for agricultural products in those countries by 
raising consumer prices, making its impact on global emissions an empirical question to be addressed in this paper.

A rough indicator of the relative magnitude of coupled price support and market price support is provided by dividing the value of producer support by the value of output at world prices, as shown in Table 1. A key feature of Table 1 is the extraordinary rate of border support in a few high-income countries, such as Japan (57\%) and Norway (63\%). Farm support rates in China are not as high, but nonetheless substantial as market price support and coupled subsidies combine to almost $15 \%$ of farm output. Also noteworthy is the negative market price support in India (-12\% of farm output) combined with sizeable coupled subsidies (7\%). Globally, the rate of support from coupled subsidies averaged 5.5\% in 2017-2019, while market price support rates averaged $5.7 \%$.

Meanwhile, greenhouse gas (GHG) emissions from agriculture are strongly concentrated in a few commodities with beef, dairy and rice accounting for over $80 \%$ of agricultural GHG emissions (Table 2). The production of these emission-intensive goods is often heavily supported using market price-support measures. This suggests a clear link between agricultural support and GHG emissions. However, the strength of this link requires close examination. At least four factors need to be considered before making any strong inferences: (i) the average rate of support to agriculture, (ii) differences between types of support, (iii) differences in rates of support across commodities, and (iv) impacts of support on production methods and processes.

The average rate of support to agriculture matters because high rates of support are likely to attract resources into agriculture, increase output and, at constant technology, increase emissions from production. The type of support matters because of its influence on overall incentives to both producers and consumers. Differences in rates of support across commodities may have important impacts on overall emissions given large differences in the emission intensity of commodities and across countries as measured by the $\mathrm{CO}_{2}$ equivalent of greenhouse gases emitted per unit of output. As noted in a related study ${ }^{2}$, output of individual agricultural commodities is likely to be more responsive to differentials in agricultural support rates than is overall agricultural output to the average rate of agricultural support.

Support intended to influence production practices and processes, such as subsidies on fertilizers, pesticides or improved seeds, also matter. In practice, these mostly aim to stimulate agricultural production which may induce more emissions unless improved practices are more 
resource efficient. Higher use of inputs such as fertilizer, may be an additional source of GHG emissions, though improved, climate-resilient seeds may help improve environmental outcomes. Some support programs, like the reformed Common Agricultural Policy of the EU, condition support on compliance with environment-friendly production and land conservation practices.

In addition to the direct support to agriculture measured in the Producer Support Estimate (PSE), OECD's reports a General Services Support Estimate (GSSE) which includes support for activities such as agricultural research, development and training, intended to raise agricultural productivity. Productivity gains tend to reduce the emission intensities of agricultural products, for instance, through changes in production processes that reduce use of intermediate inputs and reduce emission intensities (see, for example, ref. ${ }^{3}$ ).

This article focuses on the implications of current agricultural support policies on GHG emissions. It applies a rigorous model-based analysis of the impacts of incentives on agricultural outputs and emissions. This analysis provides an opportunity to consider all the influences outlined above-impacts on overall output, differences in incentives across countries and commodities, as well as differences in farm technologies and practices used for production. It also allows us to examine the extent and potential implications of environmental conditionalities incorporated in producer support measures. We consider not just the total emissions per unit of output, but also the source of those emissions - whether they are, for instance, from enteric fermentation by ruminants or from fertilizer use.

\section{The emission intensity of agricultural production}

A key parameter for understanding the impacts on climate change of agricultural support is the emission intensity of production by region, measured by the amount (in $\mathrm{kg}$ ) of $\mathrm{CO}_{2}$-equivalent greenhouse gases produced per kg of output. If production in an area with high emission intensities is replaced by production from an area with lower emission intensities, total emissions will fall. Emission intensities vary greatly across countries/regions and commodities (see Table 3 and the Methods section for further detail). The emission intensity for bovine meat is by far the largest for any food product, and it varies from 12.1 in the United States to 108.3 in India. There is a clear association between income levels and emission intensity, with the intensity for beef more than twice as high in the group of developing and emerging economies than in highincome, developed countries. Underlying this link is a strong relationship between productivity 
levels and emissions-productivity increases typically save on inputs and reduce emissions per unit of output. Tubiello ${ }^{4}$ points out that total emissions from agriculture have fallen steadily since the 1980s in the so-called Annex 1 Countries subject to emission reduction commitments under the Kyoto protocol—despite substantial increases in incomes and population.

\section{Estimating the impact of agricultural support on GHG emissions}

We estimate the impact of current agricultural support measures on GHG emissions through simulations using IFPRI's global computable general equilibrium (CGE) model, MIRAGRODEP (see Methods section), augmented with models that capture the impacts of changes in outputs and inputs on emissions. We run simulations with the MIRAGRODEP model that compare observed levels of output and emissions by country and commodity with those that would come about in the absence of the government support. We look specifically at the impacts of coupled subsidies and the border restrictions (trade measures) and simulate both the impact of each type of support and their combined impact. Supplementary Table 1 summarizes impacts on output and Table 4 summarizes the main results for emissions. More detailed findings can be found in a related working paper ${ }^{5}$.

The findings show that coupled subsidies stimulate agricultural output and emissions, while agricultural trade interventions reduce emissions (as compared with a situation without these interventions). Specifically, coupled subsidies increase global farm output volume by $0.9 \%$ (see Supplementary Table 1). Primarily because of the stimulus to production, GHG emissions from agriculture are 34,420 kt of $\mathrm{CO}_{2}$-eq higher (an increase of $0.6 \%$ ) than they would be without the coupled subsidies. The impact on emissions is smaller than the output effect, because the stimulus provided is less for the most emission-intensive products, such as beef and dairy products, and because the expansion of output resulting from subsidies is larger in richer countries with lower emission intensities. Table 4 further shows that the impact of coupled subsidies on emissions is similar in magnitude for developed and developing countries. Close to a third of the increase results from stimulus to synthetic fertilizer use.

In contrast, and perhaps surprisingly, border measures have a minuscule impact on global output, increasing it by a mere $0.1 \%$, with output rising in developed countries by $0.6 \%$ and falling in developing countries by $0.1 \%$ (Supplementary Table 1). Emissions fall by 128 million 
tons or 2.1 percent Table 4). The impact of agricultural trade protection on output is smaller than that of coupled subsidies, even though much more support is provided through protection. This is because protection raises consumer prices, reducing demand in countries that protect agriculture. The impact on emissions is also influenced by shifts in the location of output. Border measures increase output in some high-income countries with relatively low emission intensities while negative protection reduces output of high-emission-intensity bovine meat, as is the case in several developing countries.

Combined, coupled subsidies and border measures help increase global farm output by $1.1 \%$, mainly driven by higher output in the developed countries. Differences in emission intensities and price-induced shifts in demand imply that current incentives limit global GHG emissions by 102 million tons of $\mathrm{CO}_{2}$ equivalent (1.7\% of current levels) compared with a situation in the absence of such support: The support measures, on balance, provide incentives that shift production from relatively high emission-intensity countries, such as Brazil, to those with somewhat lower emission intensity, especially high-income economies, such as the EU. The highly concentrated nature of emissions by commodity and the large differences in emission intensities across countries plays a major role in this outcome. Substantially lower output of bovine meat in Brazil (18\%), India (32\%) and Australia (31\%), only partially offset by higher output in the EU and China, determine most of the estimated impact of agricultural support measures on global emissions.

\section{The importance of efficiency improvements to reduce emissions}

In sum, while many have criticized current subsidy programs as contributing to global warming, our results suggest that simply abolishing current programs could, in fact, lead to slightly higher emissions. Likely, however, there are many reforms that could be undertaken to better the current performance of agricultural support against goals such as improving economic efficiency, reducing poverty and lowering emissions. One approach which could simultaneously serve all three of these goals would be to increase the support to agricultural research and development. Many studies indicate that the economic returns from $R \& D$ focused on increasing agricultural productivity are extraordinarily high ${ }^{6}$, and agricultural productivity growth appears to have a much bigger impact on poverty reduction than productivity growth in other sectors ${ }^{7}$.

Furthermore, there is every reason to believe that research focused on reducing agricultural 
emissions - or combinations of cost and emission reduction — would substantially reduce emission intensities. While research with a strong focus on emission reductions as well as productivity increases is relatively new, there are already promising new technologies and practices that could reduce in methane emissions from rice and from cattle by up to $50 \%$ (see, for

example, ref. ${ }^{3,8}$ on dietary supplements for cattle and alternate wetting and drying in rice). Hurdles to adoption of new technologies can be formidable ${ }^{9}$, but the many types of improved farm management practices could provide substantial environmental benefits at low cost..

As illustrative examples, we considered R\&D two types of technological improvement that reduce emission intensities by $30 \%$ in the countries for which we have data on agricultural incentives. The first does so by reducing emissions per unit of output and the second by reducing all inputs per unit of output The first is like the case of dietary supplements for cattle, which reduce emissions without greatly stimulating output per unit of input. The second is more consistent with innovations like alternative wetting and drying in rice, which raises productivity of all inputs, while reducing emissions per unit.

The results of these simulations are presented in Fig. 3. The reduction of almost $20 \%$ in global emissions with a technical change that reduces emissions without raising productivity reflects simply our partial coverage of support measures. The $50 \%$ difference between the two experiments reflects the rebound effect associated with innovations that reduce the costs of producing goods and hence stimulate demand for the good, and hence lead to increases in output and emissions from that source. This estimate of the rebound effect is consistent with the estimate obtained by a recent study focusing on agricultural productivity and greenhouse gas emissions ${ }^{10}$. Both these experiments point to the potential for much larger reductions in emissions from productivity growth and, hence, from redirecting support measures to R\&D and incentives to adoption of improved practices than from reducing or eliminating current support measures.

\section{Conclusions and the agenda for further policy research}

The analysis presented in this paper examines the implications of current levels of support to farmers on global GHG emissions from agricultural production. To assess these impacts, we compared the current level of emissions with a counterfactual without these support measures. In 
this assessment, we focused on emissions from agricultural production only. This allowed us to concentrate on the complexities associated with changing these subsidies and to provide a basis for understanding more comprehensive and far-reaching reforms. For the assessment we created a new database mapping GHG emissions by source, location, commodity, production stage and technology and incorporated this information into IFPRI's global model to relate agricultural production structures and market behavior to emission-intensities by location, production sector, technology, and source of emissions.

Our findings show that current subsidies coupled to production induce both higher global agricultural output $(0.9 \%)$ and emissions $(0.6 \%)$. The existing market price support to farmers has almost no effect on global agricultural production and reduces GHG emissions by around $2 \%$. Combined, the coupled subsidies and border measures slightly increase global farm output (by $1.1 \%$ ), while reducing global GHG emissions from agriculture by around $1.7 \%$. These small net impacts arise because border measures in rich countries lower global demand more than they increase supply and induce shifts from relatively high emission-intensity producers to low emission-intensity producers. Coupled subsidies, by contrast, provide incentives to expand emission-intensive agricultural activities. The upshot is that, on balance, current agricultural subsidies and trade protection appear to have a very modest impact on global emissions. To use reform of agricultural support to make substantial reductions in emissions will require changes in the form of intervention, such as increasing emphasis on interventions that raise productivity and reduce emissions per unit of output.

These findings are preliminary and further research is needed to understand the true impacts, especially since the present scenario analysis did not consider in the impacts on land use change or on the carbon sequestration capacity of forests and soils. Furthermore, the findings should not be taken as conclusions about the effectiveness (or lack thereof) of current agricultural support policies. Present agricultural subsidy policies in most countries are largely based on political-economy considerations and rarely for their impacts on GHG emissions. Proper assessment of policy effectiveness requires assigning policies to the goal that they are to pursue most directly. Future work will also involve accounting for impacts on land use change and carbon sequestration capacity of forests and soils, , as well as additional scenarios for repurposing subsidies in ways that are more sensitive to climate mitigation and adaptation of agricultural sectors. Our tentative conclusion that simply reducing current agricultural subsidies 
has a relatively limited impact on emissions - and may even increase them-points to a need to investigate the use of the multiple instruments needed to achieve multiple goals such as economic efficiency, emission reduction, resilience and poverty reduction.

\section{References}

1. OECD. Agricultural Policy Monitoring and Evaluation 2020, (OECD Publishing, 2020).

2. Mamun, A., Martin, W., \& Tokgoz, S. Reforming agricultural subsidies for improved environmental outcomes' IFPRI Discussion Paper 1891 (International Food Policy Research Institute, 2019). https://tinyurl.com/yyj9zwn2 forthcoming Applied Economic Perspectives \& Policy

3. Mernit, J. How eating seaweed can help cows to belch less methane. Yale Environment 360, (2018; July 2) https://tinyurl.com/y2892zdh

4. Tubiello, F. Greenhouse gas emissions due to agriculture., in Ferranti, P., Berry, E.M., \& Anderson, J.R. (eds.), Encyclopedia of Food Security and Sustainability, vol. 1, pp. 196-205 (Elsevier, Amsterdam, 2019).

5. Laborde, D., Mamun, A., Martin, W., Piñeiro, V. \& Vos, R. 2020. Modeling the impacts of agricultural support policies on emissions from agriculture. IFPRI Discussion Paper, No. 1954 (International Food Policy Research Institute, 2020). https://tinyurl.com/y4cvmv5v

6. Alston, J., Pardey, P., James, J. \& Andersen, M. The economics of agricultural R\&D. Annual Review of Resource Economics 1, 537-66 (2009).

7. Ivanic, M. \& Martin, W. Sectoral productivity growth and poverty reduction: national and global impacts World Development 109, 429-39 (2018).

8. Chidthaisong, A. Evaluating the effects of alternate wetting and drying (AWD) on methane and nitrous oxide emissions from a paddy field in Thailand. Soil Science and Plant Nutrition, 64(1), 31-38 (2018).

9. Liu, E. 'Time to change what to sow: risk preferences and technology adoption decisions of cotton farmers in China. Review of Economics and Statistics 95(4), 1386-1403. (2013)

10. Valin, H., et al. 'Agricultural productivity and greenhouse gas emissions: trade-offs or synergies’ Environ. Res. Lett. 8, 1-9. (2013) 
Tables and graphs

Fig. 1. Agricultural producer support by main types of support, 2017-2019

(Billions of US\$ per year)

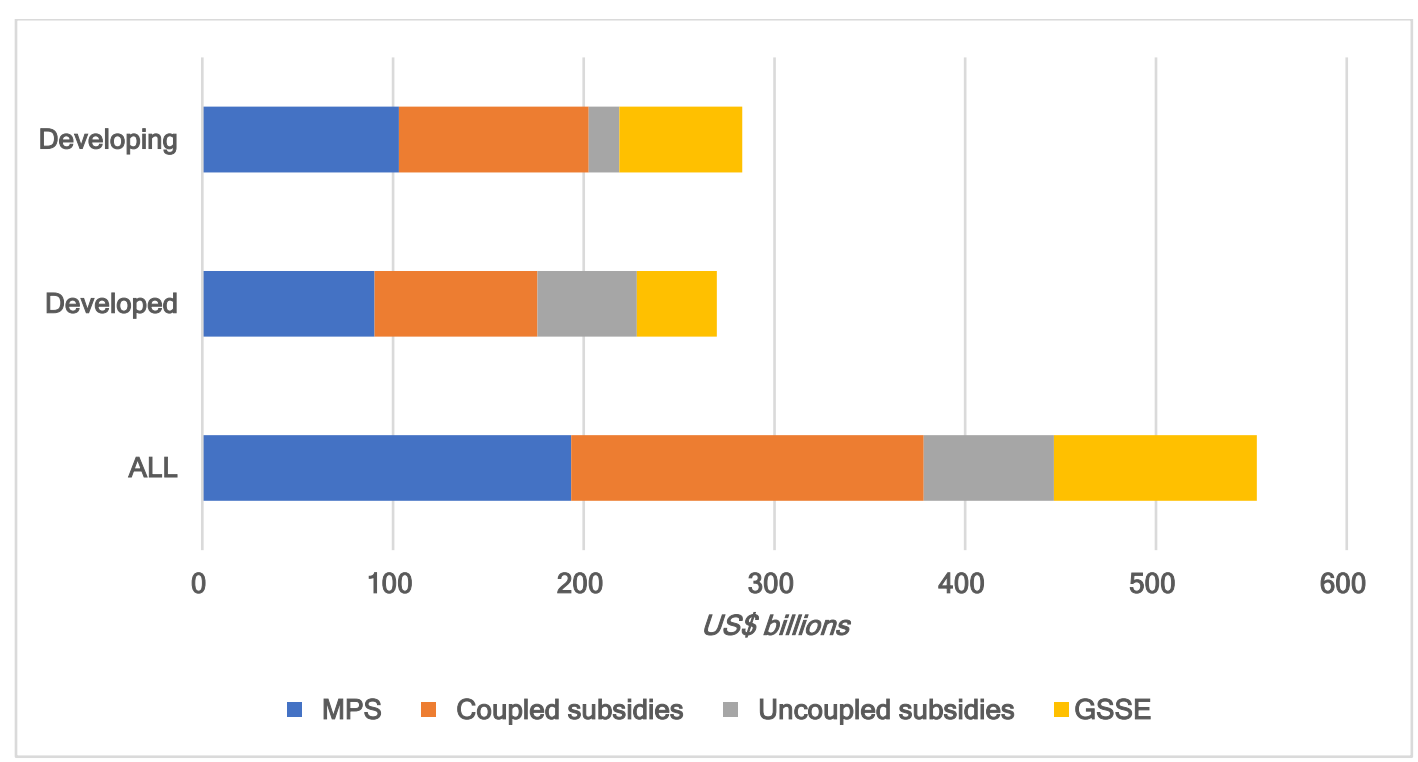

Source: Ref. ${ }^{1}$.

Table 1. Coupled subsidies vs market price support, 2017-19

(Support as \% share of value of production at world market prices)

\begin{tabular}{lrr}
\hline & $\begin{array}{c}\text { Coupled } \\
\text { Subsidies }\end{array}$ & $\begin{array}{c}\text { Market Price } \\
\text { Support }\end{array}$ \\
\hline Australia & 1.4 & 0.0 \\
Brazil & 1.5 & 0.2 \\
Canada & 3.8 & 4.6 \\
China & 4.2 & 10.1 \\
EU28 & 9.8 & 4.1 \\
India & 6.7 & -12.1 \\
Japan & 8.6 & 57.0 \\
Mexico & 5.2 & 5.2 \\
Norway & 80.9 & 62.9 \\
Russia & 4.2 & 6.8 \\
South Africa & 1.1 & 3.4 \\
USA & 7.5 & 3.2 \\
Developed countries & 8.1 & 8.5 \\
Developing countries & 4.3 & 4.4 \\
Total & 5.5 & 5.7 \\
\hline
\end{tabular}

Source: Ref. ${ }^{1}$. 
Table 2. GHG emissions (in CO2 eq) from agriculture by commodity, 2014 (Shares in percent)

\begin{tabular}{lrrr}
\hline & $\begin{array}{r}\text { Developed } \\
\text { countries }\end{array}$ & $\begin{array}{r}\text { Developing } \\
\text { countries }\end{array}$ & World \\
\hline Rice & 3.7 & 18.6 & 15.6 \\
Other cereals & 19.2 & 7.2 & 9.7 \\
Milk & 20.6 & 17.4 & 17.9 \\
Ruminant meat & 46.4 & 51.5 & 49.4 \\
Pig meat & 7.6 & 3.1 & 4.0 \\
Poultry meat & 1.3 & 1.3 & 1.3 \\
\hline
\end{tabular}

Source: Authors' calculations based on FAOSTAT.

Table 3. Emission intensities for key products, countries and country groupings, 2013-2015 ( $\mathrm{kg} \mathrm{CO}_{2}$ eq. per $\mathrm{kg}$ of production)

\begin{tabular}{lrrrrrrr}
\hline & $\begin{array}{r}\text { Cereals } \\
\text { excl. } \\
\text { rice }\end{array}$ & Eggs & $\begin{array}{r}\text { Bovine } \\
\text { meat }\end{array}$ & Chicken & $\begin{array}{c}\text { Pig } \\
\text { meat }\end{array}$ & Milk & Rice \\
\hline Australia & 0.3 & 0.4 & 20.2 & 0.2 & 2.5 & 0.7 & 0.7 \\
Brazil & 0.2 & 0.8 & 35.7 & 0.3 & 2.6 & 1.2 & 0.5 \\
China & 0.3 & 0.6 & 16.9 & 0.6 & 1.0 & 1.1 & 0.8 \\
EU & 0.2 & 0.7 & 15.4 & 0.3 & 1.6 & 0.6 & 3.0 \\
India & 0.3 & 0.5 & 108.3 & 0.5 & 5.0 & 1.1 & 0.7 \\
Indonesia & 0.2 & 1.0 & 42.8 & 3.6 & 4.9 & 2.9 & 1.1 \\
Japan & 0.2 & 0.4 & 9.5 & 0.3 & 0.9 & 0.3 & 0.8 \\
Mexico & 0.2 & 0.5 & 28.1 & 0.5 & 2.8 & 0.5 & 3.4 \\
Russia & 0.1 & 1.0 & 15.0 & 0.3 & 1.3 & 0.8 & 2.2 \\
USA & 0.2 & 0.5 & 12.1 & 0.3 & 2.0 & 0.4 & 1.1 \\
Developed countries & 0.2 & 0.6 & 15.3 & 0.3 & 1.7 & 0.6 & 1.2 \\
Developing countries & 0.2 & 0.7 & 32.2 & 0.7 & 1.4 & 1.3 & 0.9 \\
World & 0.2 & 0.7 & 26.5 & 0.6 & 1.5 & 1.0 & 0.9 \\
\hline
\end{tabular}

Source: Authors' calculations based on FAOSTAT. See Ref. ${ }^{5}$ for further detail. 
Table 4. Impact of current agricultural support (coupled subsidies and border measures) on GHG emissions from agriculture by source, 2014-16 (Kt of $\mathrm{CO}_{2}$ eq.)

\begin{tabular}{|c|c|c|c|c|c|c|c|}
\hline & All & $\begin{array}{c}\text { Crop } \\
\text { Residues }\end{array}$ & $\begin{array}{c}\text { Enteric } \\
\text { Fermentation }\end{array}$ & Manure & Rice & $\begin{array}{l}\text { Synthetic } \\
\text { Fertilizer }\end{array}$ & $\begin{array}{c}\text { Energy and } \\
\text { other }^{a}\end{array}$ \\
\hline \multicolumn{8}{|c|}{ Coupled subsidies } \\
\hline World & 34,420 & 2,915 & 6,016 & 3,871 & 1,041 & 10,138 & 10,439 \\
\hline Developed & 18,116 & 1,079 & 4,107 & 2,987 & 206 & 4,942 & 4,795 \\
\hline Developing & 16,304 & 1,836 & 1,909 & 884 & 834 & 5,197 & 5,644 \\
\hline \multicolumn{8}{|c|}{ Border measures } \\
\hline World & $-127,635$ & $-4,129$ & $-91,043$ & $-39,624$ & 1,193 & $-1,203$ & 7,171 \\
\hline Developed & $-25,597$ & $-3,115$ & $-11,644$ & $-9,139$ & -201 & $-3,042$ & 1,544 \\
\hline Developing & $-102,037$ & $-1,013$ & $-79,399$ & $-30,486$ & 1,394 & 1,839 & 5,628 \\
\hline \multicolumn{8}{|l|}{ All support ${ }^{b}$} \\
\hline World & $-102,071$ & $-1,257$ & $-88,780$ & $-37,691$ & 2,331 & 7,511 & 15,815 \\
\hline Developed & $-7,590$ & $-1,728$ & $-7,529$ & $-6,086$ & 33 & 1,811 & 5,909 \\
\hline Developing & $-94,481$ & 471 & $-81,251$ & $-31,605$ & 2,298 & 5,700 & 9,906 \\
\hline
\end{tabular}

Source: MIRAGRODEP simulations. See Ref. ${ }^{5}$ for further detail.

Note: a. "Energy \& other", includes emissions from energy use, as well as from burning crops and Savanna.

b. "All support" refers here to coupled subsidies and border measures. Please note that the columns do not add precisely because of nonlinearity in the relationships considered. 
Fig. 2. Impact of current coupled subsidies and border measures on GHG emissions by commodities and selected countries and country groupings

(Absolute change from counterfactual without such support; kt of $\mathrm{CO}_{2}$ eq.)

a. Major developed countries and country groupings

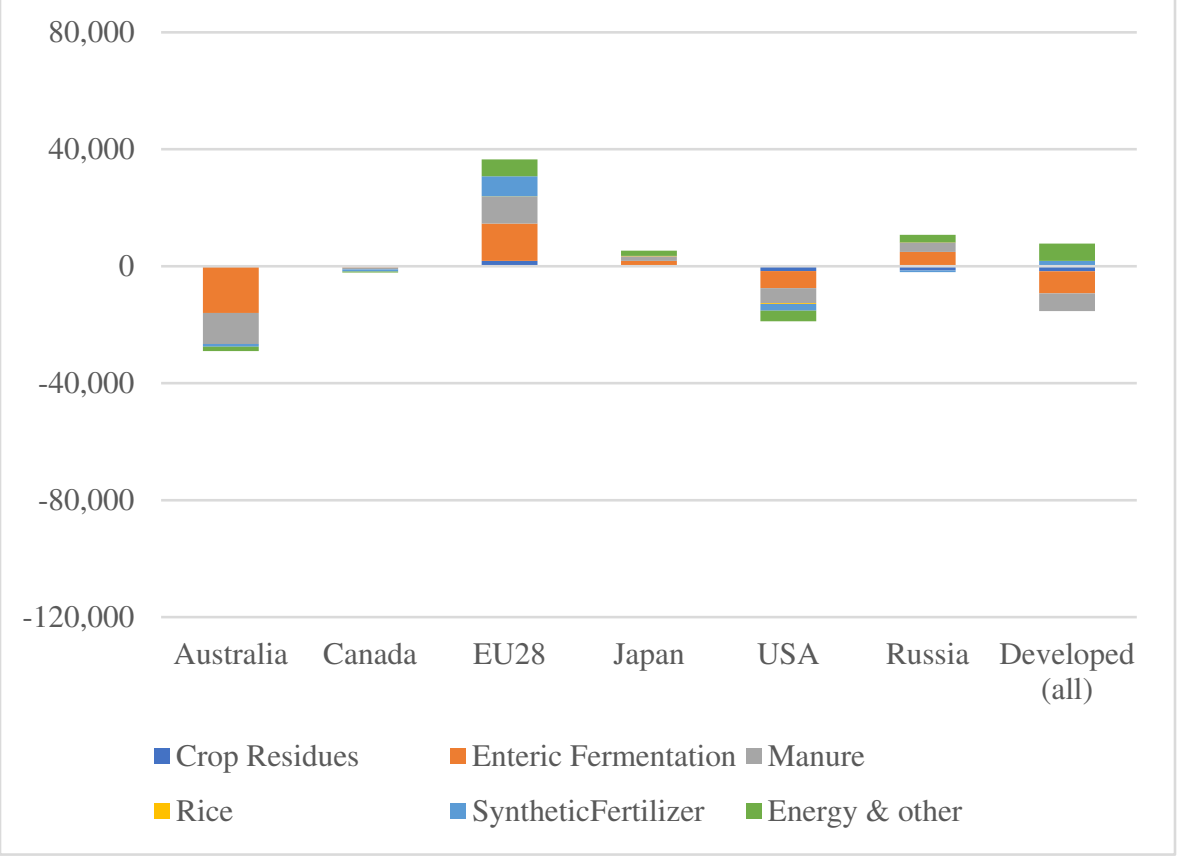

b. Major developing and emerging economies

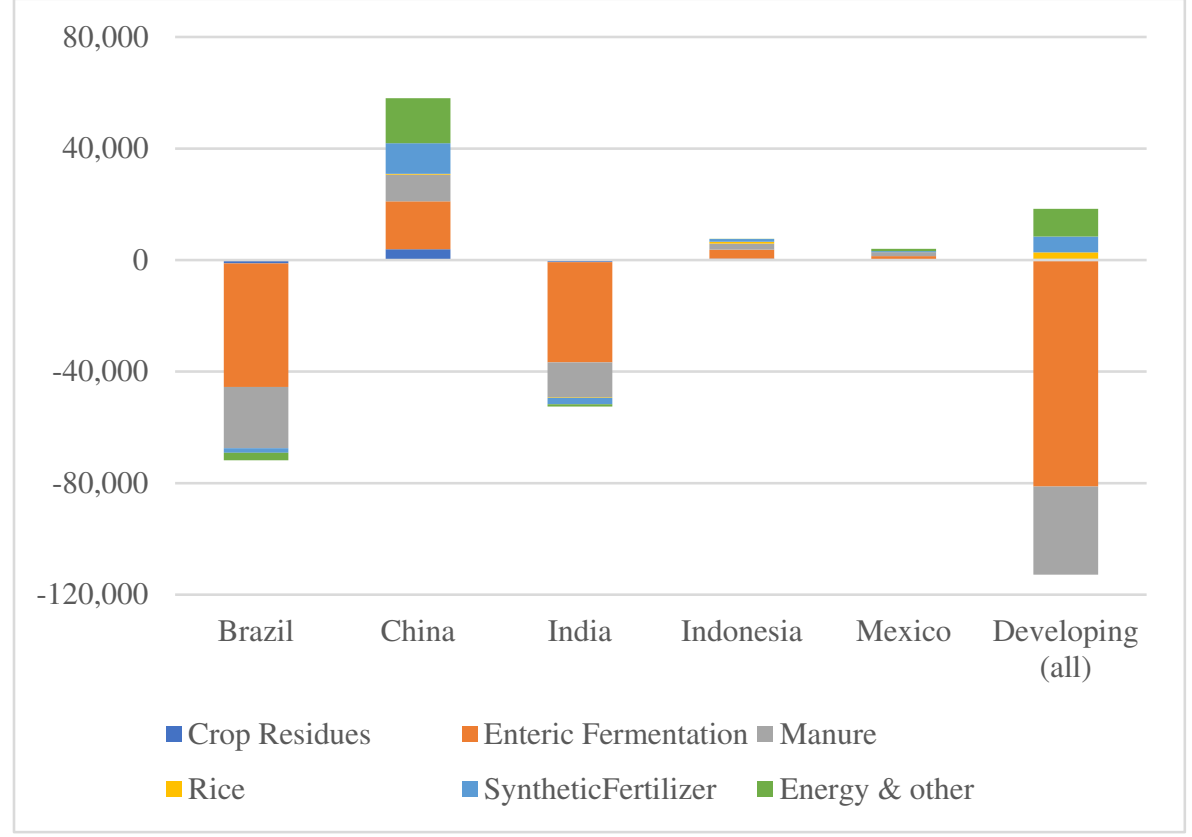

Source: MIRAGRODEP simulations. See Ref. ${ }^{5}$ for further detail. 
Fig. 3. Impact of 30 percent reductions in emission-intensities with and without agricultural productivity increases

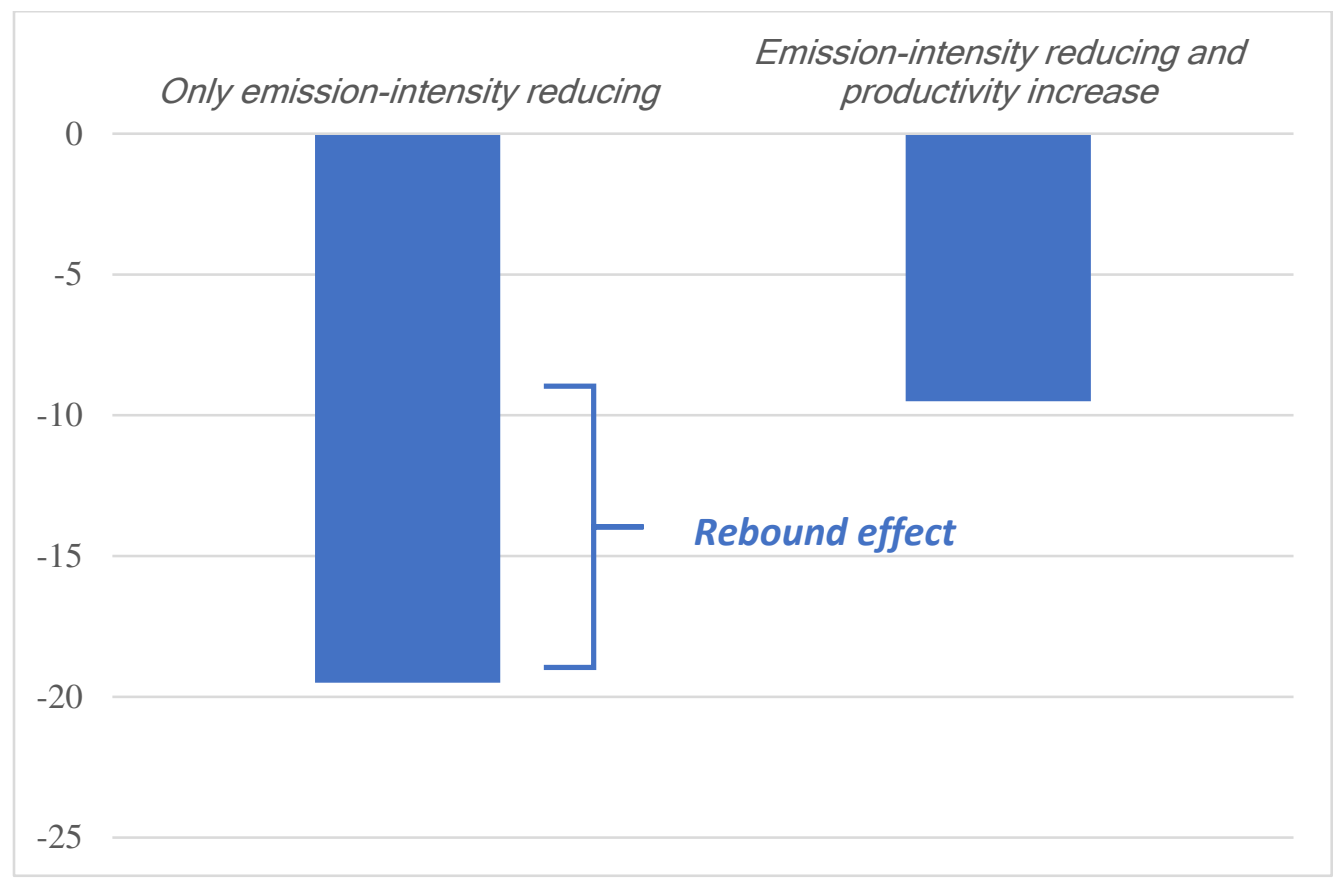

Source: MIRAGRODEP simulations. See Ref. ${ }^{5}$ for further detail. 


\section{METHODS}

\section{Emissions database by drivers}

For this study, we created a new database of emissions in agricultural production. FAOSTAT presents vectors of data on emissions by type and by commodity for each country, but we need the full matrix of emissions by type, commodity, and source to allow us to consider changes in emissions by type in production of each commodity, such as reductions in emissions from enteric fermentation in beef production. Wherever possible, we derived this full matrix by reverse engineering the FAO emission data to ensure that the total matched the FAOSTAT estimates. Where this was not possible, as in the case of emissions from pesticides, we used a similar IPCC Tier 1 methodology to generate comparable estimates.

Emission sources are identified using eleven FAOSTAT-based categories included in Table A.1 plus emissions from agricultural pesticides. The first step was to define the activity levels associated with commodity outputs, such as the area used for rice cultivation. The second was to calculate the emission coefficients (EC) for $\mathrm{CH}_{4}, \mathrm{CO}_{2}$ and $\mathrm{N}_{2} \mathrm{O}$ by activity level using, wherever possible, the FAOSTAT database. Finally, emissions of $\mathrm{N}_{2} \mathrm{O}$ and $\mathrm{CH}_{4}$ were converted to $\mathrm{CO}_{2}$ equivalents using 310 and 21 for $\mathrm{N}_{2} \mathrm{O}$ and $\mathrm{CH}_{4}$ respectively.

In many cases, the FAOSTAT emission database provided implied emission factors by activity and emission source, such as the area harvested in rice cultivation and the nitrogen content of manure. In some cases, it provides the base activity data, such as areas of organic soil cultivation; and the number of head of livestock for enteric fermentation and manure management. In other cases, such as burning crop residues, only data on biomass burned are provided, rather than data on the crops burned. In such cases, we imported base activity data from the FAOSTAT crop and livestock production database for the crops whose residues are frequently burned-maize, rice, sugar cane and wheat.

For synthetic nitrogen fertilizer, the activity data (i.e., agricultural use of nitrogen) is missing. We obtained fertilizer use data from two sources - FAOSTAT (http://www.fao.org/faostat/en/\#home) and the International Fertilizer Association (www.ifastat.org ). FAOSTAT gives the total fertilizer volume for a large number of countries, while the IFA's Fertilizer Use by Crop data provide the nutrient content of fertilizer by crop for 54 countries. Fertilizer use data from FAOSTAT were scaled to match IFA numbers for all 
countries and this was done by mapping the characteristics of IFA countries to the countries listed in FAOSTAT. Finally, we estimated emissions by multiplying fertilizer volume by the emission coefficients given in FAOSTAT database. For the final version of the database, we retained the base activity (or index) data to estimate the average amount of emissions per index type (land, animals, output, fertilizer and energy). The process for creating of this new database is presented schematically in Fig. A.1.

\section{Fig. A.1. Creation of database of GHG emission from agriculture by source, location, commodity, production stage and technology}

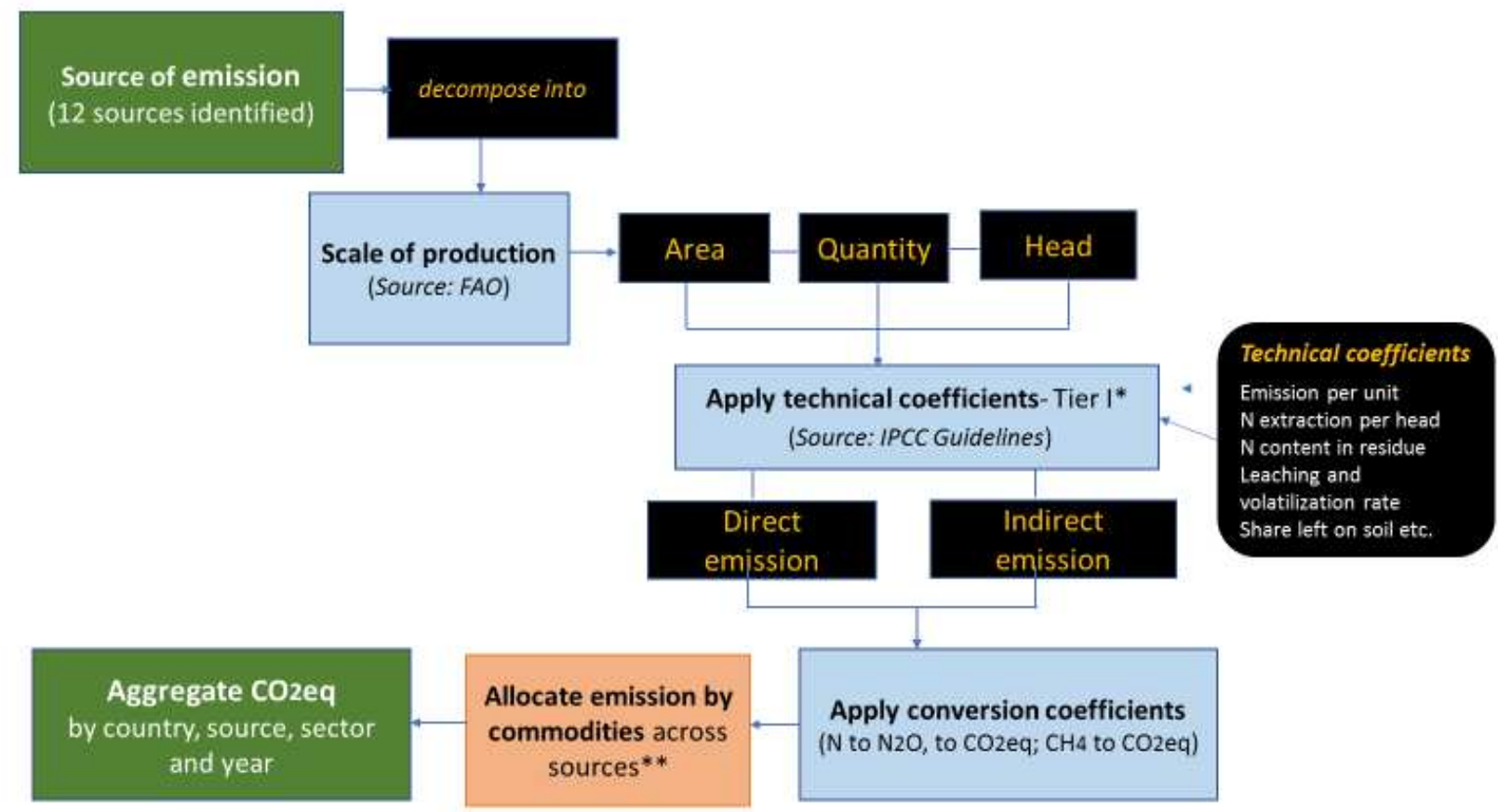

Source: Authors' depiction

Notes: * Tier I: Default emission factors from IPCC guidelines (2006); ** Using disaggregation space and linkage matrix

To allocate emissions from enteric fermentation and manure management between the joint products of meat and milk (and wool in the case of sheep) from buffaloes, camels, cattle, goats and sheep in line with the value of their products. The resulting livestock numbers were then linked to emissions using data from the FAOSTAT emissions database. In the final step we produced emissions data by country, emission source and commodity. A summary of the overall structure of the emission shares is presented in Table A.1. 
Table A.1: Shares of GHG emissions from agriculture by commodity and source, 2015 (\% of total, excluding energy)

\begin{tabular}{|c|c|c|c|c|c|c|c|c|}
\hline & Rice & $\begin{array}{c}\text { Other } \\
\text { Cereals }\end{array}$ & Milk & $\begin{array}{l}\text { Ruminant } \\
\text { meat }\end{array}$ & Pig meat & $\begin{array}{l}\text { Poultry } \\
\text { meat }\end{array}$ & Eggs & Total \\
\hline Burning crops & 0.2 & 0.5 & 0.0 & 0.0 & 0.0 & 0.0 & 0.0 & 0.7 \\
\hline Crop residue & 1.3 & 3.1 & 0.0 & 0.0 & 0.0 & 0.0 & 0.0 & 4.4 \\
\hline Enteric fermentation & 0.0 & 0.0 & 11.0 & 30.5 & 0.6 & 0.0 & 0.0 & 42.1 \\
\hline Manure management & 0.0 & 0.0 & 1.6 & 2.4 & 2.8 & 0.4 & 0.3 & 7.5 \\
\hline Manure left on pasture & 0.0 & 0.0 & 3.6 & 13.3 & 0.0 & 0.7 & 0.4 & 18.0 \\
\hline $\begin{array}{l}\text { Manure applied to } \\
\text { soils }\end{array}$ & 0.0 & 0.0 & 1.0 & 1.1 & 0.9 & 0.7 & 0.4 & 4.2 \\
\hline Pesticides & 0.2 & 0.8 & 0.0 & 0.1 & 0.0 & 0.0 & 0.0 & 1.1 \\
\hline Rice cultivation & 12.6 & 0.0 & 0.0 & 0.0 & 0.0 & 0.0 & 0.0 & 12.6 \\
\hline Synthetic fertilizers & 2.4 & 6.5 & 0.0 & 0.7 & 0.0 & 0.0 & 0.0 & 9.6 \\
\hline Total & 16.6 & 10.9 & 17.1 & 48.1 & 4.3 & 1.8 & 1.1 & 100.0 \\
\hline
\end{tabular}

Source: Authors' computation. Note: Data in the table are global averages.

\section{Modeling approach}

To assess the impacts of current agricultural support, we examine the implications of moving from current support levels to a hypothetical situation in the absence of intervention. For this analysis, we use IFPRI's global computable general equilibrium (CGE) model, MIRAGRODEP. It is an extension of the widely-used MIRAGE model of the global economy ${ }^{11}$. The model was developed and improved with the support of the African Growth and Development Policy Modeling Consortium (AGRODEP). It is a multi-region, multi-sector, dynamically recursive CGE model. The model allows for a detailed and consistent representation of the economic and trade relations between countries ${ }^{12}$. In each country, a representative consumer maximizes a CES-LES (Constant Elasticity of Substitution-Linear Expenditure System) utility function subject to an endogenous budget constraint to generate the allocation of expenditures across goods. This functional form replaces the Cobb-Douglas structure of the Stone-Geary function (that is, LES) with a CES structure that retains the ability of the LES system to incorporate different income elasticities of demand ${ }^{13}$, with those for food typically lower than those for manufactured goods and services. The demand system is calibrated on the income and price elasticities estimated by Muhammad et al. ${ }^{14}$. Once total consumption of each good has been determined, the origin of the goods consumed is determined by another CES nested structure, 
following the Armington assumption of imperfect substitutability between imported and domestic products.

On the production side, demands for intermediate goods are determined through a Leontief production function that specifies intermediate input demands in fixed proportions to output. Total value added is determined through a CES function of unskilled labor and a composite factor of skilled labor and capital. This specification assumes a lower degree of substitutability between the last two production factors. In agriculture and mining, production also depends on land and natural resources.

The underlying database used for the analysis is Pre-release 3 of the GTAP v10 database for 2014 (www.gtap.org). This database includes 141 regions/countries and 65 products. It includes updated Social Accounting Matrices for all individually specified countries and updated estimates of agricultural support measures based on measures of average domestic support provided by $\mathrm{OECD}^{1}$, but adjusted to include the impacts on bilateral protection rates of major trade preferences. A realistic baseline is constructed aligned with the United Nations' demographic projections and updated IMF economic growth estimates to bring the base year values (2011) to those of the actual year of simulation (2020)

The data on agricultural support were adjusted in line with the measures discussed in the article for agricultural border measures and subsidies that influence output or input decisions (coupled subsidies). The model was augmented with a post-solution module based on the new emission database presented above and which links GHG emissions to output and inputs of agricultural activities determined in the model. This linkage is presented schematically in Fig. A.2. The combined model was then used to assess the impacts of policy reform on emissions of $\mathrm{CH}_{4}, \mathrm{CO}_{2}$ and $\mathrm{N}_{2} \mathrm{O}$, and these results combined to generate a total $\mathrm{CO}_{2}$ equivalent. 
Fig. A.2 Linking the emissions module to the production system as captured in IFPRI's

\section{MIRAGRODEP model}

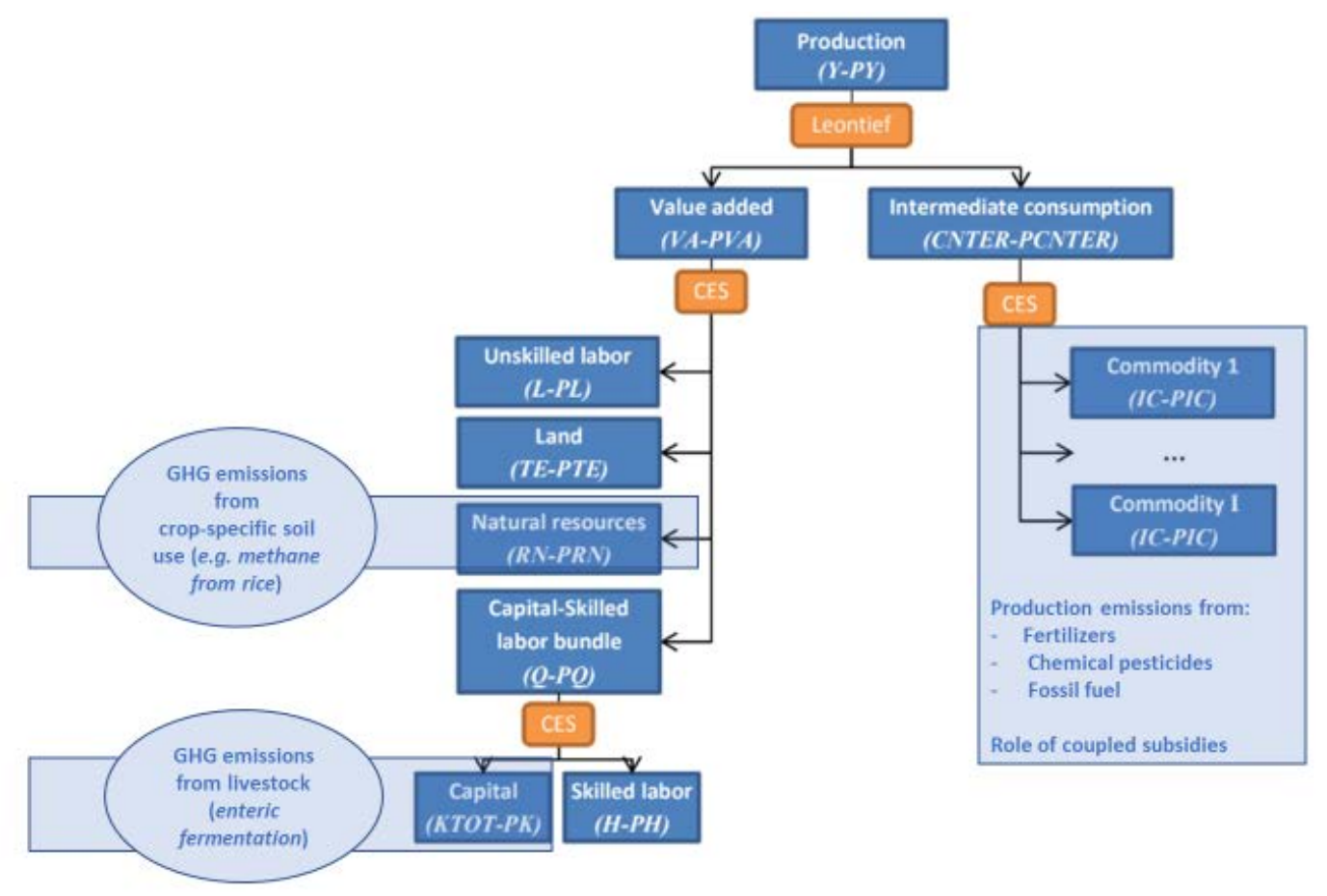

Source: Authors' depiction.

The macroeconomic assumptions used for the analysis were designed to be relatively "neutral" to avoid situations where macroeconomic adjustments such as real exchange rate changes outweigh the impacts of interest, and to allow us to focus on the impacts of agricultural support policies on emissions. These assumptions were:

(i) no dynamic effects of investment decisions (the static version of the model was used);

(ii) aggregate real public expenditures are kept constant and a consumption tax is adjusted to keep the government budget balance fixed as a share of GDP;

(iii) land use is constant to focus on emissions from agricultural production;

(iv) total employment is constant.

Our approach of holding land use constant is consistent with many other studies in this area (e.g.., ref. ${ }^{15}$ ), and allows us to focus on changes in emissions from agricultural production, without needing to address the impacts of land use change, which are very context specific. 
Having estimates of the impacts on agricultural emissions is an important building block towards a full understanding of the impacts of reform. In this paper, we begin by considering the impact of removing coupled subsidies, and then turn to border measures.

\section{References to Methods section}

11. Decreux, Y.\& Valin, H., 'MIRAGE, Updated version of the model for trade policy analysis focus on agriculture and dynamics. CEPII Working Paper 2007-15, (CEPII, 2007). http://www.cepii.fr/PDF_PUB/wp/2007/wp2007-15.pdf

12. Laborde, D., Robichaud, V. \& Tokgoz, S., MIRAGRODEP 1.0: Technical documentation' AGRODEP technical note. (IFPRI, 2013).

13. Stone, R. Linear expenditure systems and demand analysis: an application to the pattern of British demand. The Economic Journal, 64, 511-27. (1954)

14. Muhammad, A., D’Souza, A. Meade, B. Micha, R. \& Mozaffarian, D. The influence of income and prices on global dietary patterns by country, age, and gender. Economic Research Report No. ERR-225, (US Department of Agriculture, 2017).

https://www.ers.usda.gov/publications/pub-details/?pubid=82544

15. Henderson, B. \& Lankoski J. 'Evaluating the environmental impact of agricultural policies", OECD Food, Agriculture and Fisheries Papers, No. 130. (OECD Publishing, 2019). http://dx.doi.org/10.1787/add0f27c-en

16. IPCC. 2006 IPCC Guidelines for National Greenhouse Gas Inventories, Prepared by the National Greenhouse Gas Inventories Programme, Eggleston H.S., Buendia L., Miwa K., Ngara T. and Tanabe K. (eds). Institute for Global Environmental Strategies, Japan (2006). https://www.ipcc-nggip.iges.or.jp/public/2006gl/vol4.html 


\section{Supplementary Table:}

Supplementary Table 1. Changes in Output Following Removal of Coupled Subsidies and Border Measures $(\%)^{\mathrm{a}}$

\begin{tabular}{|c|c|c|c|c|c|}
\hline & Farm & Beef & Dairy & Rice & Pork/Poultry \\
\hline \multicolumn{6}{|c|}{ Coupled Subsidies } \\
\hline Australia & 1.7 & 1.4 & 1.1 & 1.0 & 0.5 \\
\hline Brazil & 0.3 & 0.4 & 0.0 & -1.5 & 1.1 \\
\hline China & -1.1 & -0.1 & 0.1 & -1.6 & -0.4 \\
\hline$E U$ & -3.4 & -3.5 & -1.5 & -1.4 & -2.5 \\
\hline India & -1.7 & -2.1 & 0.2 & -2.9 & -1.2 \\
\hline Indonesia & -0.3 & -0.3 & 0.6 & -0.4 & 0.1 \\
\hline Japan & -2.9 & -3.2 & -3.8 & -0.4 & -0.3 \\
\hline Mexico & -3.3 & -7.0 & 0.0 & 1.0 & -4.2 \\
\hline Russia & -1.6 & -0.5 & -3.5 & -0.8 & -2.3 \\
\hline$U S A$ & 0.0 & 0.1 & -0.2 & 1.0 & 0.7 \\
\hline Developed & -1.7 & -1.1 & -1.3 & -0.3 & -1.2 \\
\hline Developing & -0.5 & -0.2 & 0.3 & -1.0 & -0.3 \\
\hline World & -0.9 & -0.7 & -0.6 & -0.9 & -0.6 \\
\hline \multicolumn{6}{|c|}{ Border Measures } \\
\hline Australia & 20.9 & 31.2 & 40.2 & 22.3 & 2.7 \\
\hline Brazil & 11.1 & 18.1 & -1.1 & -2.9 & 19.4 \\
\hline China & -3.6 & -3.6 & -39.6 & -1.1 & -0.1 \\
\hline$E U$ & -1.3 & -12.8 & 7.1 & -20.1 & -2.1 \\
\hline India & 2.4 & 32.0 & 3.5 & 6.2 & 0.7 \\
\hline Indonesia & -5.2 & -24.2 & -0.8 & -9.0 & -5.0 \\
\hline Japan & -21.8 & -32.6 & -64.7 & -4.4 & -22.7 \\
\hline Mexico & -2.2 & 5.0 & -1.7 & -2.4 & -10.3 \\
\hline Russia & -8.8 & -11.7 & -14.1 & -11.5 & -10.6 \\
\hline$U S A$ & 4.9 & 3.8 & 8.7 & 29.6 & 4.8 \\
\hline Developed & -0.6 & -3.0 & 1.4 & -3.3 & -1.3 \\
\hline Developing & 0.1 & 2.7 & -3.5 & -0.2 & 1.3 \\
\hline World & -0.1 & -0.2 & -0.9 & -0.4 & 0.3 \\
\hline
\end{tabular}

Source: MIRAGRODEP simulations. See Ref. ${ }^{5}$ for further detail.

Note: Please note that the results in this table are shown as "counterfactuals", that is, what output would be in the absence of support measures relative to the existing situation. A negative value indicates therefore that existing support helps increase agricultural output. 


\section{Figures}

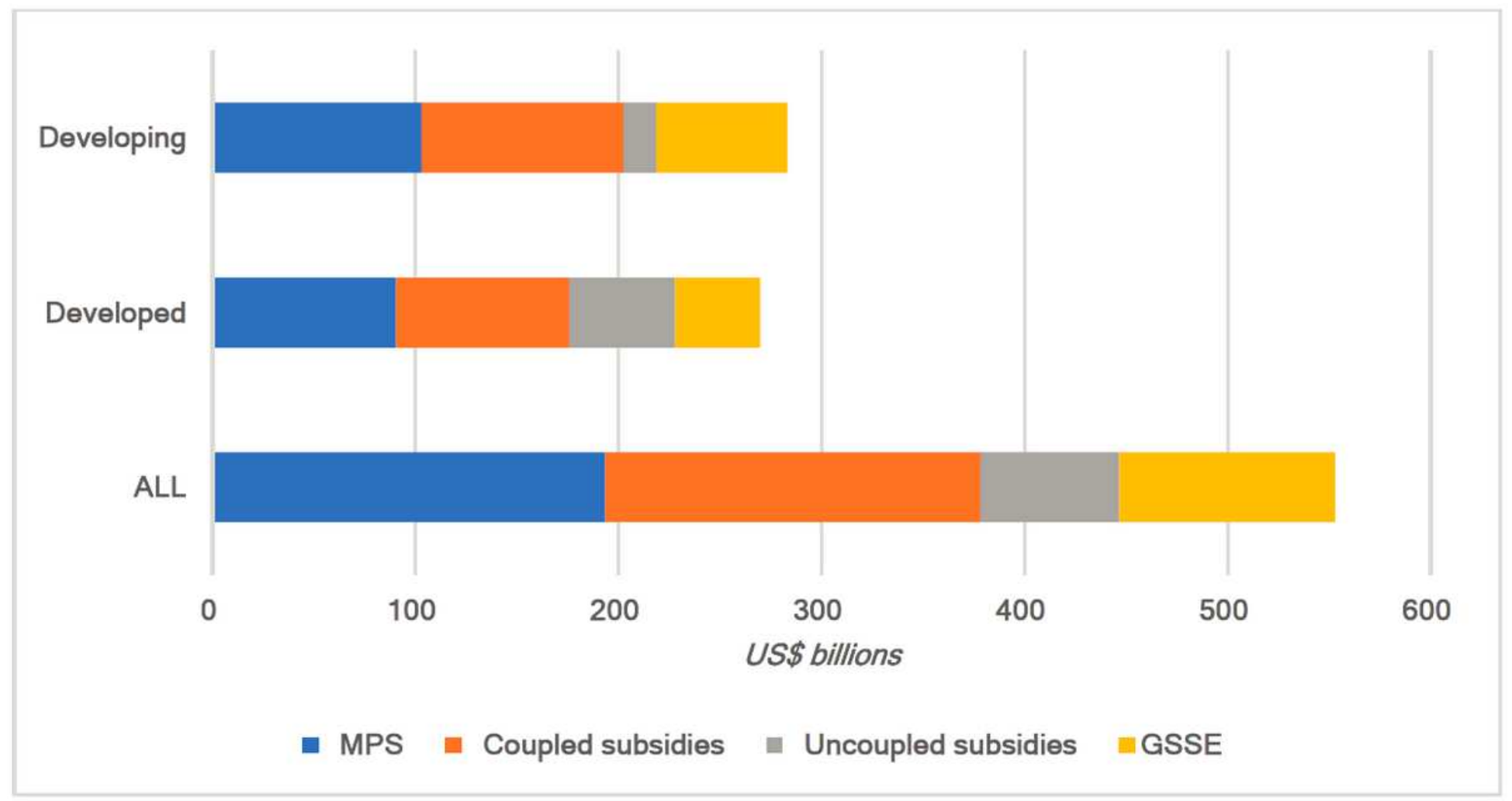

\section{Figure 1}

Agricultural producer support by main types of support, 2017-2019 (Billions of US\$ per year) Source: Ref. 1. 


\section{a. Major developed countries and country groupings}

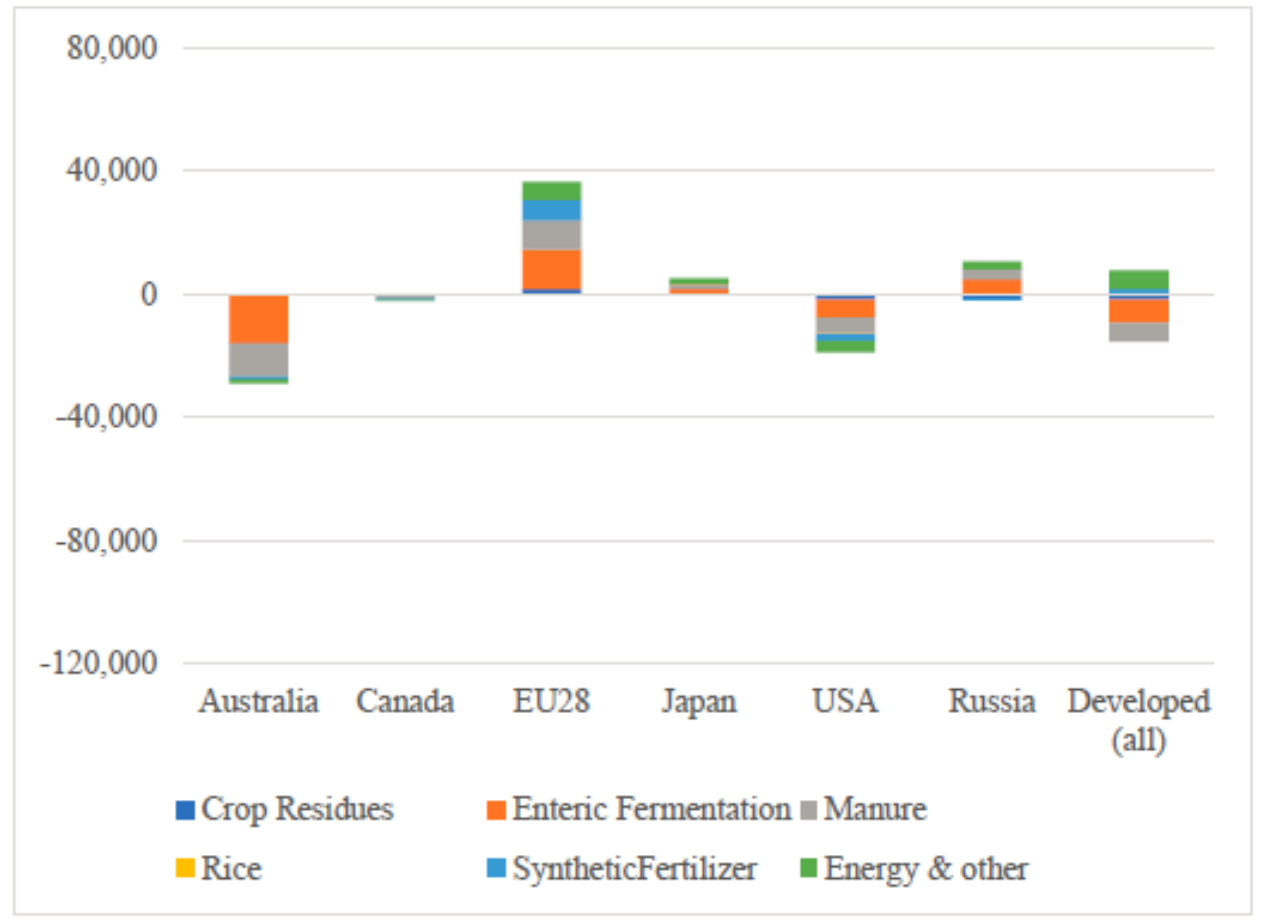

\section{b. Major developing and emerging economies}

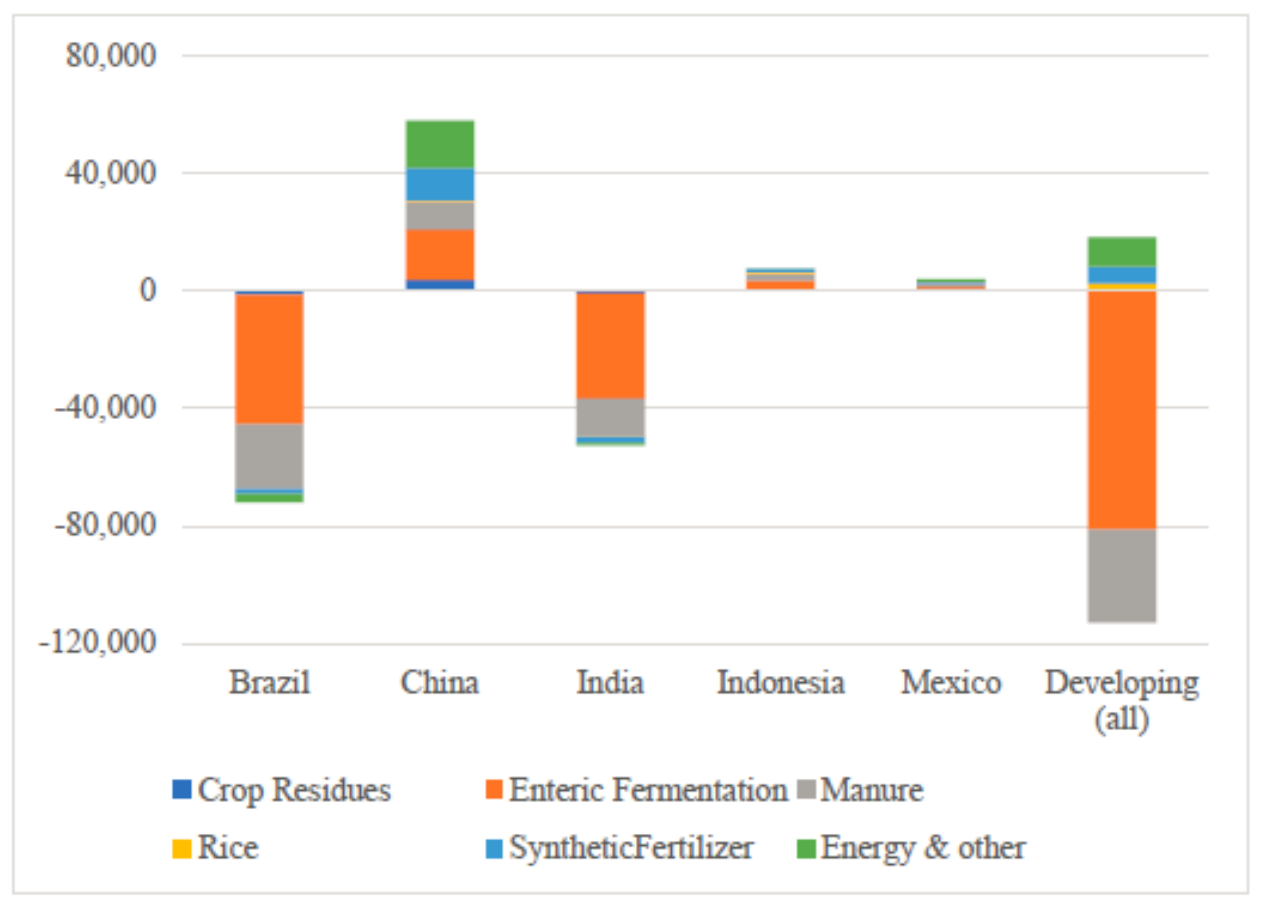

\section{Figure 2}

Impact of current coupled subsidies and border measures on GHG emissions by commodities and selected countries and country groupings (Absolute change from counterfactual without such support; $\mathrm{kt}$ of CO2 eq.) Source: MIRAGRODEP simulations. See Ref. 5 for further detail. 


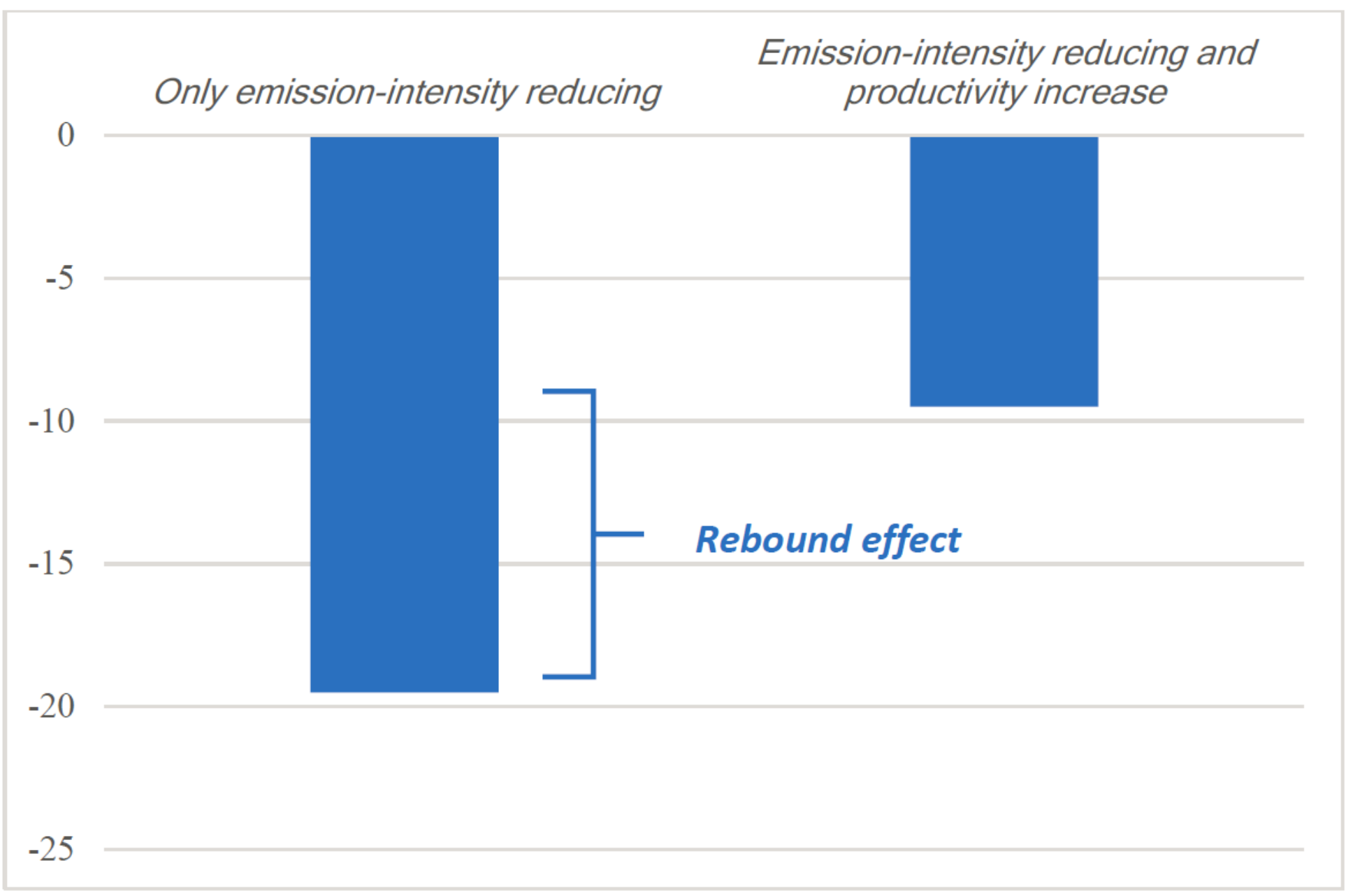

\section{Figure 3}

Impact of 30 percent reductions in emission-intensities with and without agricultural productivity increases. Source: MIRAGRODEP simulations. See Ref. 5 for further detail. 